\title{
In reply: In defense of succinylcholine
}

\author{
Orlando R. Hung, MD, FRCPC 1 - Dolores McKeen, MD, FRCPC • \\ Johannes Huitink, MD, PhD
}

Received: 6 October 2016/Accepted: 12 October 2016/Published online: 21 October 2016

(C) Canadian Anesthesiologists' Society 2016

\section{To the Editor,}

We thank Dr. Falkenstein for his thought-provoking response $^{1}$ to our editorial ${ }^{2}$ and for sharing the story of his love-hate relationship with succinylcholine. To continue in the vein of his metaphorical dialogue, we would like to offer our advice to Dr. Falkenstein.

While we all like to reminisce about the "good old days" and those "friends on the edge of acceptability" who we invited to our parties, the truth is that we did not actually have a lot of friends from which to choose. Fortunately, many decades later, the maturing of anesthesia practice has brought many changes to our invitation list, including rocuronium and sugammadex.

Most contemporary anesthesiologists have embraced the practice of evidence-based medicine to provide a safer anesthetic to their patients with minimal adverse effects. Since its introduction into clinical practice, hundreds of published papers have reported adverse events associated with the use of succinylcholine, ${ }^{3}$ making it unwise to ignore the overwhelming evidence of the associated complications of succinylcholine. Dr. Falkenstein's own anecdotal experience (e.g., "... I have never seen more than 'two monitor screens' of asystole in response to a second (or third, or fourth, or fifth...) dose of Sux [succinylcholine]..." arguably may not fully reflect what we know to be true.

O. R. Hung, MD, FRCPC ( $₫) \cdot$ D. McKeen, MD, FRCPC Department of Anesthesia, Dalhousie University, Victoria General Hospital, Halifax, NS, Canada

e-mail: hung192@gmail.com

J. Huitink, MD, PhD

Department of Anesthesia, VU University Medical Center, Amsterdam, The Netherlands
In other words, we cannot be too sentimental about our "bad" friends even though we have luckily been well served by them in the past. We must embrace what is best for our patients, even if it lies outside our comfort zone. As prudent practitioners, we must not continue to have parties inviting socially unacceptable friends (i.e., sux), who may behave badly (producing dysrhythmias, hyperkalemia, and myalgia, among other complications) and sometimes leave us and those under our care with potentially fatal consequences (e.g., asystole, malignant hyperthermia triggering, pseudocholineresterase deficiency issues). ${ }^{4}$ We understand that the incidence of severe adverse events with succinylcholine is very low, but we should not be complacent about its risks.

We were dismayed with Dr. Falkenstein's statement that “...I found myself more disturbed by the potential 'legal' ramifications to the anesthesiologist involved than by the consequences to the patient...." We do care about what happened to our patients. Ironically, Dr. Falkenstein wrote how he tolerated and accepted his "imperfect friend" Sux and that he would continue to invite his friend to his party even though there is a potential that this friend would harm a patient and have serious consequences. As we have matured based on the results of clinical investigations performed over many decades, we know that we must now care less about our traditions and comfort and more about our responsibility for patient safety.

As indicated in our informal survey in our editorial ${ }^{2}$ on the use of succinylcholine around the world since the introduction of sugammadex, many of our anesthesiologist colleagues have not used succinylcholine for years. As suggested in our editorial, we do not think that we will be abandoning succinylcholine anytime soon, but together with sugammadex and rocuronium we remain prepared to host a final farewell party for Dr. Falkenstein's friend, Sux. 
Conflicts of interests None declared.

Editorial responsibility This submission was handled by Dr. Hilary P. Grocott, Editor-in-Chief, Canadian Journal of Anesthesia.

\section{References}

1. Falkenstein $R$. In defense of succinylcholine. Can J Anesth 2017; 64. DOI: $10.1007 / \mathrm{s} 12630-016-0758-\mathrm{z}$.
2. Hung $O$, McKeen D, Huitink J. Our love-hate relationship with succinylcholine: Is sugammadex any better? Can J Anesth 2016; 63: 905-10.

3. Wong SF, Chung F. Succinylcholine-associated postoperative myalgia. Anaesthesia 2000; 55: 144-52.

4. Gronert GA. Cardiac arrest after succinylcholine: mortality greater with rhabdomyolysis than receptor upregulation. Anesthesiology 2001; 94: 523-9. 